\title{
IMPACT OF TEACHERS' CLASSROOM BEHAVIOURS ON STUDENTS' LEARNING AT SECONDARY SCHOOL LEVEL IN QUETTA DISTRICT, BALUCHISTAN, PAKISTAN
}

\author{
Muhammad Ehsan
}

Virtual University of Pakistan

Email: ehsankhangp@gmail.com

ORCID ID: (1)https://orcid.org/0000-0000-0002-7253

Received: 09 ${ }^{\text {rd }}$ July, 2020; Revised: $24^{\text {th }}$ July, 2020; Accepted $16^{\text {th }}$ August, 2020

\begin{abstract}
Introduction: In the field of learning, the relationship between a teacher and student is of notable importance. Classroom is a learning place where students spend a significant amount of time with their teachers.

Purpose: This study was initiated to check how negatively or positively teachers can affect the learning process of their students in classroom with their behaviours. Similar type of studies were conducted before as well, but this study was necessary in Quetta, Pakistan, because of increasing amount of drop-outs of children from secondary schools in the city. Hence, due to new wave of terrorism in the city, the study was kept limited.

Methodology: A total of 200 respondents from ten high schools of Quetta city took part in this study. Survey method was used and the data had been compiled on a Likert scale with closed ended statements. After the data was collected, it was analyzed in SPSS software. Cross-tabulation was applied on the data and also Mean of the responses was derived from each statement. Basically, two major factors followed by sub-statements were taken into consideration for the study to find out their impact.

Results: The end results showed mixed results. In some cases teacher's strict behaviours puts positive impact too.

Recommendations: It is essential for teachers to gain thorough understanding and implications of the behaviours to attain high level of efficiency in the classroom. Hence, democracy is essential and teachers should align their behaviours.
\end{abstract}

Keywords: Secondary Schools, Students' Learning, Classroom, Teacher's Behavior.

\section{Cite paper as:}

Crossref Ehsan, M. (2020). Impact of teachers' classroom behaviours on students' Cited-by learning at secondary school level in Quetta district, Baluchistan, Pakistan. Journal of Educational Research in Developing Areas, 1 (1), 20-32. https://doi.org/10.47434/JEREDA.1.1.2020.20

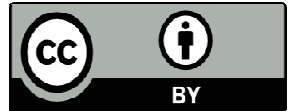

Copyright (c) 2020 The author(s) of this article retain(s) the copyright.

\section{PUBLIC INTEREST STATEMENT}

This research article eyes at the possible impacts of a teachers' classroom behaviours on students' learning at secondary school grades. Considering the potential relationship between the two, the article puts a little effort to add a limited knowledge into the pool of already existing studies on the same issue. As education is among the top priorities of the United Nations SDGs, which is the concern of every individual. Therefore, this piece of research based writing addresses this common interest. 
Journal of Educational Research in Developing Areas (JEREDA)

Vol. 1. Issue 1, Pp. 20-32, Inaugural Edition, 2020

http://www.jeredajournal.com

E-mail: info@jeredajournal.com

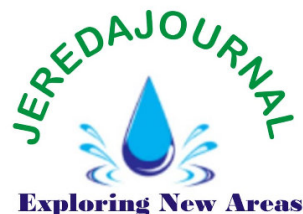

\section{INTRODUCTION}

As Skinner (2019) writes that behaviour is human response or reaction to its surroundings or to the outer world. Behaviour of a teacher with students means interaction and the mode of communication between them. The fundamental reason for this aspect is to explore the effect of teacher's behaviour on learning of secondary school students. Mundy (1999) defines that behaviour is to direct or hold oneself in what we do, particularly in the light of outside effects anything that a living being does that includes activity and reaction to incitement. Behaviour is a detectable, identifiable portent (Prochaska, Clemente \& Norcross, 1992). It is behaviour that develops human personality. Human beings learn from each other. All human beings are connected with each other in such a way that what one does with the other, the other does the same with others. Usually, every single community reflects the same behavioural norms psychologically. In the same way, a student resembles in his or her whole life what he or she learns in the classroom, because a student spends a significant amount of his or her school-going age in classroom. It is a common observation of the writer of this article that in whatever way a teacher treats or behaves with students in the class puts a significant impact on the overall learning and development of the students at school and these students when enter into practical life, they often behave in the same way what has been printed on their minds back in school. Hence, it is very important to know the impact of teacher's classroom behaviour on students' learning, as students always consider teachers as their heroes.

Soroya, Hashmi and Soroya (2014) argue that, teachers have influence on the students. Students imitate them and catch an inspiration from them, consciously or unconsciously. Teacher's behaviours and attitudes instantly influences the lives of the students and that a teacher puts lots of efforts on their students, in order to make them workable and highly authentic. They observe and judge each and every action of their teachers. They also noted in their study that the success of any school is visibly linked with the teaching faculty it

has. If teaching faculty is good \& up to the standard, the school produces remarkable students and achieves sound reputation. Similarly, Shah (2009) revealed in his study that students' learning is directly influenced by the positive behaviour of teacher. Classroom atmosphere could be where students do not get worried while committing errors, and where there are strong associations with companions and seniors on whom students can depend (Mercer \& De-Rosier, 2010). Also, a huge amount of our senior teachers and our religious folks are in the favour of soft punishment to children when they commit negligence in discharging their tasks. It is also the researcher's own observation that without punishment children hardly accomplish their home-work and that a little punishment proves good to compel children to stay on the track. Jane (2016) says that strict discipline must be reimplemented in schools which was banned in 1970's. She further argues, researchers found that the countries having strict discipline rules in their schools were performing more than expectations academically. On the other hand, it is very unfortunate that a huge amount of our teachers severely punish their students on petty mistakes particularly at school level. Due to the advancement of electronic media now-a-days some of these happenings are being highlighted on media, but most of these happenings go unreported. It has been noticed that most of the students leave their study in the mid of their school education just because of the harsh treatment of their teachers. In our society especially in Baluchistan, people are poor and backward. Due to poverty, even school-going children of middle and secondary classes do a parttime jobs after their school. So, the students do not complete their assignments or homework on time, due to which teachers punish them.

Secondly, it has also been seen that some teachers do not punish their students at all, even if they commit any negligence or break the discipline. So, sometimes, they face misbehaviour. So it is also very important to investigate what impact is put on the students as a result of the teacher's attitudes in the classroom. From the studies mentioned above, it can be said that being 
Journal of Educational Research in Developing Areas (JEREDA)

Vol. 1. Issue 1, Pp. 20-32, Inaugural Edition, 2020

http://www.jeredajournal.com

E-mail: info@jeredajournal.com

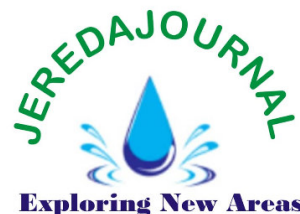

a human, a teacher may differently behave in class on different occasions. So, the researcher is interested in understanding the impacts set in the learning process of the students as a result of the particular behaviour of the teachers in classroom at secondary school level. As at secondary class level students are at their teenage, which is very delicate period of a child's development and the children are very sensitive at this stage (Somerville, 2013).

\section{STATEMENT OF THE PROBLEM}

Learning needs passion, and that passion is produced in children by different factors and inspirations. This inspiration may be their parents, their relatives, their society, their environment and their teachers. The level of inspiration that a teacher puts on student is greater than all, because children spend a significant amount of their time with their teachers during their education. The success of every child is connected with a teacher and learning environment. In this age of competition, education is not only a personal concern of everyone, but it has become a national concern. It is also a general assumption that teacher's classroom behaviours are considerable factors on students' morale, learning, and the outcomes need to be observed. Keeping in view the critical importance of secondary level of education, it specifically seems quite viable to investigate and determine the effects of teacher's behaviour on academic progression of the students, therefore, understanding both teachers and students' perception is crucial. In order to give thorough education and information to the students, both the students and teachers have to play their roles. The teachers should have the audacity and the required knowledge through which they can transform the knowledge and information to the students. The students on the other hand are more likely to concentrate. This research will bridge the requirements in order to analyze the perception of the secondary school teachers regarding the effects of the teacher's classroom behaviour on the learning of the students, and serve as a vital tool towards improving learning environment.

Volume 1, Number 1 (Inaugural Edition)

\section{PURPOSE OF THE STUDY}

1. To determine the perception of secondary school students regarding the effects of strict behaviour of teachers on their learning?

2. To determine the perception of secondary school teachers regarding the impact of inappropriate language used by the teachers in classroom?

3. To determine the perception of secondary school teachers regarding the impact of inappropriate language used by the teachers in the classroom.

4. To determine the perception of secondary school students regarding the impact of inappropriate language used by the teachers in the classroom.

\section{RESEARCH QUESTIONS}

1. What is the perception of secondary school teachers regarding the effects of strict behaviours of teachers on their learning?

2. What is the perception of secondary school students regarding the effects of strict behaviours of teachers on their learning?

3. What is the perception of secondary school teachers regarding the impact of inappropriate language used by the teachers in the classroom?

4. What is the perception of secondary school students regarding the impact of inappropriate language used by the teachers in the classroom?

\section{METHODOLOGY}

Quantitative research methodology is a research methodology which allows researchers to make a more comprehensive study in a less time and permits generalizability (Flick, 2015). It is used to inquire or study a social problem by gathering numerical data and conducting statistical analysis. It has been chosen to find out the impact of teachers' classroom behaviour on students' learning at secondary school.

\section{Research Design}

In this study, descriptive research method has been used to know the impact of teachers' classroom behaviour on the learning of students at secondary school 
Journal of Educational Research in Developing Areas (JEREDA)

Vol. 1. Issue 1, Pp. 20-32, Inaugural Edition, 2020

http://www.jeredajournal.com

E-mail: info@jeredajournal.com

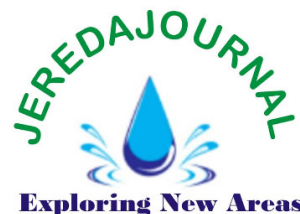

level. The recent study followed quantitative research methodology approach, and a survey was conducted in the target population.

\section{Population and Sample}

Population of this study are secondary schools of Quetta, Baluchistan, Pakistan. Confronted with the fragile law \& order situation and limited resources, the

study was confined to only those schools of Quetta city that were more convenient and more reachable. Only ten $(\mathrm{N}=10)$ high schools were chosen for the study on the basis of convenient random sampling. Hence, the sampled population along with total population of the chosen study area; is provided in the below table 1 .

Table 1: Population of the targeted study area

\begin{tabular}{lcc}
\hline Population Subjects & Total & Sampled \\
\hline Secondary schools & 17 & 10 \\
Secondary school teachers & 220 & 100 \\
Secondary school students & 1230 & 100 \\
\hline
\end{tabular}

http://www.emis.gob.pk/

Initially, convenient sampling technique was adopted which is a nonprobability sampling technique, to select schools for the study. Afterwards, stratified random sampling was used to obtain the population for the study. As there were two categories i.e. teachers and students, so in the beginning, the sampled population was grouped and stratified. To avoid bias, both teachers and students were chosen randomly. A total of two hundred $(\mathrm{N}=200)$ respondents were chosen for this study, which included hundred $(\mathrm{N}=100)$ secondary school teachers and hundred $(\mathrm{N}=100)$ students of secondary education classes. From each school, ten secondary school teachers and ten secondary school students were picked for the research which means 20 respondents from each school.

\section{Instrument for Data Collection}

For the current study, the research instrument was developed in the form of a questionnaire based on a five point Likert scale i.e. Never, Rarely, Sometimes, Often, and Always. Questionnaire was comprised of sixteen closed ended statements preceded by two factors/headings. Each factor/heading was developed in such a way that it linked the topic and each statement was built in such a way that it linked the factor/heading. The basic rationale behind using the close ended questionnaire is because of its ability to collect the relevant data in a professional and verified manner. Table 2 shows number of statements for each factor in the survey instrument.

Table 2: Data collection factors

\begin{tabular}{ll}
\hline Factors & No. of statements \\
\hline Strictness of teacher results in & 10 \\
Inappropriate language used by the teacher & 6 \\
\hline
\end{tabular}

In the pre-analysis stage, screening and cleaning of the data was assessed that checked normality and also applied Cronbach's Alpha score to know the questionnaire inner cohesion to make it workable in applying needed statistical method in SPSS. Before putting the data into SPSS, it is very essential to make the data reliable. In this regard the data was checked to fix errors and also removed errors from the data files. Moreover, checking normality of the data is also very 


\section{Journal of Educational Research in Developing Areas (JEREDA) Vol. 1. Issue 1, Pp. 20-32, Inaugural Edition, 2020 \\ http://www.jeredajournal.com \\ E-mail: info@jeredajournal.com}

important because this will assume that the data is normally distributed and it is the key for applying statistical tools and statistics used different method to know the

The below Histogram also add contribution to normality of data that the data curve is normally distributed which shows normality. Figure 1 shows the Mean of the data is 198.8450 with the standard

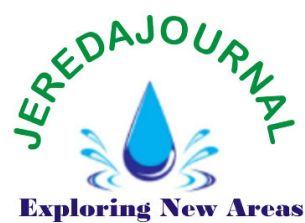

normality but the current study has used skewness and kurtoses, mean, standard deviation, and Cronbach's Alpha to know the normality.

deviation of 23.45, and Skewness is the extent to which a distribution differs from a normal distribution and Kurtosis that identifies whether the tails of a given distribution contain extreme values or not.

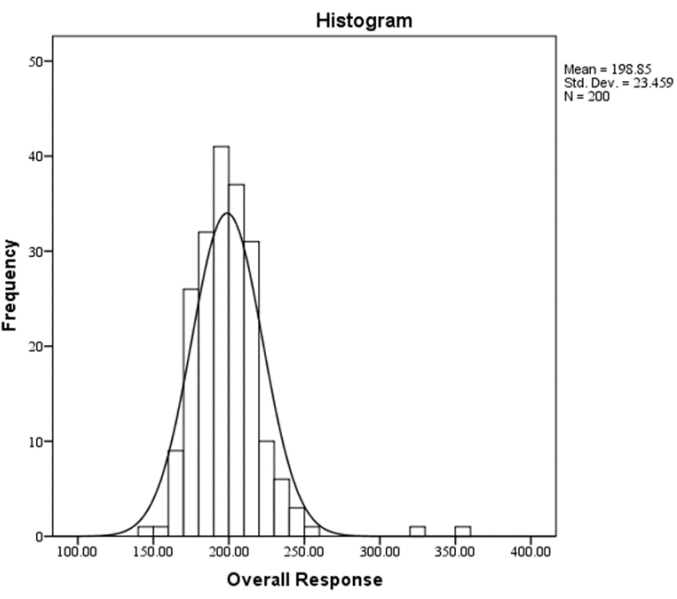

Figure 1: Histogram of Overall Responses Frequency Distribution

After the development of the research instrument, survey was conducted among the sampled population and the data then was compiled and was arranged for the further process.

\section{Procedure of Data Analysis}

After the collection of data and after putting the questionnaires in a sequence, the data was put into SPSS version 20 for the analysis. The data was analysed in SPSS by applying percentages categorywise. Each statement from the questionnaire was matched and assessed with the categories of the respondents in the cross-tabulation to find out the respective percentages of the responses. Furthermore, mean value of each response factor-wise and Mean value and St. Deviation value of each factor was also derived in SPSS. To test the reliability of the survey instrument, Cronbach's Alpha was applied to the Mean values of the responses on Likert Scale. The results of cross-tabulation and Mean of each factor were then interpreted.

\section{Method(s) of Data Analysis}

A total of two headings/factors were provided in the study instrument, and under each heading/factor certain statements were given in an attempt to know the impact of teacher's classroom behavior on students' learning. The first factor was "Strictness of The Teacher Results In". Strict behaviour is commonly seen in teachers especially at the school level. So, this factor was included to know the positive and negative outcomes of the strict behaviour of the teachers. Similarly, the second factor was "Inappropriate Language Used by The Teacher". Under this heading six statements were added regarding what negative impacts are observed on the students when a teacher uses inappropriate language in classroom.

\section{RESULTS}

Research Question 1: What is the perception of secondary school teachers regarding the effects of strict behaviours of teachers on their learning? 
Journal of Educational Research in Developing Areas (JEREDA)

Vol. 1. Issue 1, Pp. 20-32, Inaugural Edition, 2020

http://www.jeredajournal.com

E-mail: info@jeredajournal.com

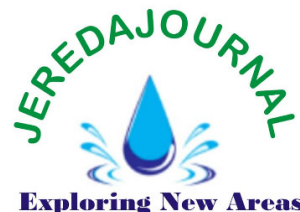

Table 3: Percentage and mean of perception of teachers regarding the effects of strict behaviours of teachers on students' learning

\begin{tabular}{|c|c|c|c|c|c|c|}
\hline \multirow[b]{2}{*}{ Statements } & \multicolumn{5}{|c|}{ Teachers } & \multirow[b]{2}{*}{ Mean } \\
\hline & Always & Often & Sometimes & Rarely & Never & \\
\hline $\begin{array}{l}\text { Improvement in the learning } \\
\text { speed of the students. }\end{array}$ & 20 & 35 & 31 & 7 & 7 & 3.54 \\
\hline $\begin{array}{l}\text { Punctuality among the } \\
\text { students. }\end{array}$ & 30 & 50 & 16 & 4 & 0 & 4.06 \\
\hline $\begin{array}{l}\text { More attentiveness in the } \\
\text { class. }\end{array}$ & 28 & 36 & 24 & 8 & 4 & 3.76 \\
\hline $\begin{array}{l}\text { Leading the student towards } \\
\text { inferiority complex. }\end{array}$ & 12 & 20 & 27 & 30 & 11 & 2.92 \\
\hline $\begin{array}{l}\text { Fading the inner Talents of } \\
\text { the students. }\end{array}$ & 15 & 24 & 22 & 27 & 12 & 3.03 \\
\hline $\begin{array}{l}\text { Widening the gap between } \\
\text { the teacher and the } \\
\text { students. }\end{array}$ & 21 & 20 & 34 & 12 & 13 & 3.24 \\
\hline $\begin{array}{l}\text { Making the students fed up } \\
\text { of their studies. }\end{array}$ & 9 & 28 & 32 & 18 & 13 & 3.02 \\
\hline $\begin{array}{l}\text { Decreasing the interest of } \\
\text { the students in their } \\
\text { studies. }\end{array}$ & 8 & 25 & 29 & 20 & 18 & 2.85 \\
\hline $\begin{array}{l}\text { Making the students stick to } \\
\text { their studies } \& \text { accomplish } \\
\text { their assignments in time. }\end{array}$ & 32 & 41 & 16 & 8 & 3 & 3.91 \\
\hline $\begin{array}{l}\text { Producing more chances of } \\
\text { the dropout of the students. }\end{array}$ & 9 & 24 & 28 & 17 & 22 & 2.81 \\
\hline
\end{tabular}

The above table shows the responses of teachers about the result of the strict behaviours of teachers. In this regard, while responding to the first statement i.e. strict behaviour of the teachers results in improvement in the learning speed of the students or in other words, teachers' strict behaviour compels students to learn more quickly. So, in response to this, 20 teachers completely agreed with the statement that this happens always. While only 7 teachers indicate 'Never' in response. In addition to this, 35 teachers mark 'Often' in response to it. So, This implies that strict behaviour of teachers improves students' speed of learning. The second statement was strictness of the teachers results in punctuality among the students or in other words students become more punctual when their teachers adopt strict behaviour. In response to this statement, 30 teachers marked 'Always', while, 50 teachers marked 'Often', and no teacher or very few teachers seemed disagreeing to this statement. Thus, It can deduce that teachers' strictness encourage punctuality among students. Third statement was strictness of the teachers results in more attentiveness in the class. In other words, due to the strict behaviour of the teachers, students sit more attentively in class. As per teachers' analysis, 28 teachers said 'Always' in response and 36 teachers ticked the option of 'Often'. While only 4 teachers disagreed to this by marking 'Never'. Hence, majority endorsed the statement.

Furthermore, fourth statement was strictness of the teachers result in leading the students towards inferiority complex. 


\section{Journal of Educational Research in Developing Areas (JEREDA) Vol. 1. Issue 1, Pp. 20-32, Inaugural Edition, 2020 \\ http://www.jeredajournal.com \\ E-mail: info@jeredajournal.com}

Responding to this statement, 12 teachers said 'Always' and 11 teachers said 'Never' in response. However, 27 teachers marked the option of 'Sometimes' in its response. Therefore, majority teachers did not think that this statement holds ground. Fifth statement was strictness of the teacher results in fading the inner talents of the students. In response, 15 teachers marked 'Always' while, 24 teachers marked 'Rarely'. Similarly, 12 teachers said 'Never', and 22 teachers said 'sometimes'. It means majority teachers were not in favour of this statement. Sixth statement was strictness of teachers result in widening the gap between the teachers and the students. As per teachers' analysis, 21 teachers ticked 'Always' while, 13 teachers marked 'Never'. Hence, 34 teachers said 'Sometimes'. So, majority teachers did not agree with this statement. Seventh statement was strictness of the teachers result in making the students fed up of their studies. As a response, 9 teachers marked 'Always', while, 13 teachers marked 'Never'. Hence, 32 teachers said 'Sometimes'. So, in this statement the responses of the teachers seemed almost equal on both the sides i.e. in favour of the statement and against the statement. But, still majority of the teachers agreed with the statement.

Eighth statement was strictness of the teachers result in decreasing the interest of the students in their studies. As per teachers' analysis, 8 teachers said 'Always'. Similarly, 18 teachers said 'Never'. But 29 teachers said 'Sometimes'. The response of the teachers for this statement seemed also the same as for the seventh statement. Ninth statement was strictness of the teachers result in making the students stick to their studies \& accomplish their assignments in time. As per teachers' analysis, 32 teachers said 'Always' whereas, only 3 teachers said 'Never' in response to this statement. Hence, 41 teachers said 'Often' in response. Thus, majority of the teachers agreed with this statement. The tenth and the final statement in this context were strictness of the teachers result in producing more chances of the dropout of the students from school. In response to it, only 9 teachers ticked 'Always' while, 22 teachers said 'Never'. However, 28 teachers said 'Sometimes'. Therefore, apparently teachers seemed somewhat ambivalent in response to this statement.

Research Question 2: What is the perception of secondary school students regarding the effects of strict behavior of teacher on students' learning?

Table 4: Percentage and mean of perception of students regarding the effects of strict behaviours of teachers on students' learning 
Journal of Educational Research in Developing Areas (JEREDA)

Vol. 1. Issue 1, Pp. 20-32, Inaugural Edition, 2020

http://www.jeredajournal.com

E-mail: info@jeredajournal.com

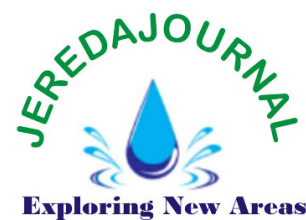

\begin{tabular}{|c|c|c|c|c|c|c|}
\hline \multirow[b]{2}{*}{ Statements } & \multirow[b]{2}{*}{ Always } & \multirow[b]{2}{*}{ Often } & \multicolumn{3}{|l|}{ Students } & \multirow[b]{2}{*}{ Mean } \\
\hline & & & Sometimes & Rarely & Never & \\
\hline $\begin{array}{l}\text { Improvement in the } \\
\text { learning speed of the } \\
\text { students. }\end{array}$ & 48 & 29 & 13 & 4 & 6 & 4.09 \\
\hline $\begin{array}{l}\text { Punctuality among the } \\
\text { students. }\end{array}$ & 54 & 31 & 11 & 2 & 2 & 4.33 \\
\hline $\begin{array}{l}\text { More attentiveness in the } \\
\text { class. }\end{array}$ & 47 & 28 & 17 & 5 & 3 & 4.11 \\
\hline $\begin{array}{l}\text { Leading the student } \\
\text { towards inferiority } \\
\text { complex. }\end{array}$ & 9 & 14 & 36 & 14 & 27 & 2.64 \\
\hline $\begin{array}{l}\text { Fading the inner Talents of } \\
\text { the students. }\end{array}$ & 14 & 17 & 18 & 21 & 30 & 2.64 \\
\hline $\begin{array}{l}\text { Widening the gap between } \\
\text { the teacher and the } \\
\text { students. }\end{array}$ & 19 & 19 & 18 & 9 & 35 & 2.78 \\
\hline $\begin{array}{l}\text { Making the students fed } \\
\text { up of their studies. }\end{array}$ & 9 & 15 & 26 & 12 & 38 & 2.45 \\
\hline $\begin{array}{l}\text { Decreasing the interest of } \\
\text { the students in their } \\
\text { studies. }\end{array}$ & 7 & 14 & 17 & 16 & 46 & 2.20 \\
\hline $\begin{array}{l}\text { Making the students stick } \\
\text { to their studies } \& \\
\text { accomplish their } \\
\text { assignments in time. }\end{array}$ & 71 & 15 & 8 & 5 & 1 & 4.50 \\
\hline $\begin{array}{l}\text { Producing more chances of } \\
\text { the dropout of the } \\
\text { students. }\end{array}$ & 7 & 13 & 19 & 16 & 45 & 2.21 \\
\hline
\end{tabular}

However, students' response on "strictness of the teachers result in can be seen in the above table. Rresponding to the first statement on strictness of the teachers result in improvement in the learning speed of the students. 48 students said 'Always' in response to this statement, only 6 students opted 'Never' in response. In addition to this, 29 students marked 'Often' in response to it. So, it could easily be said that majority of students agreed with the statement. The second statement was strictness of the teachers result in punctuality among the students. In response, 54 students marked 'Always' and no student or very few students seemed disagreeing to it. Hence, majority of students accepted the statement. Third statement was; strictness of the teacher Volume 1, Number 1 (Inaugural Edition) results in more attentiveness in the class. As response, 47 students said 'Always' while, only 3 students disagreed to this by marking 'Never'. So, majority of the students agreed with the statement. Fourth statement was strictness of the teachers results in leading the students towards inferiority complex. In response, 9 students said 'Always' and 27 students said 'Never' in response. However, 36 students marked the option of 'Sometimes'. Therefore, majority of the students stood with the view that neither it happens always, nor it can be denied as a whole but, sometimes students fall into the inferiority complex as a result of the strict behavior of the teachers. Fifth statement was strictness of the teachers results in fading the inner talents of the students. In response, 14 
Journal of Educational Research in Developing Areas (JEREDA)

Vol. 1. Issue 1, Pp. 20-32, Inaugural Edition, 2020

http://www.jeredajournal.com

E-mail: info@jeredajournal.com

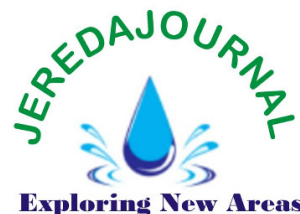

students marked 'Always' while, 21 students marked 'Rarely'. Similarly, 30 students said 'Never', and 18 students said 'Sometimes'. So, majority of the students believed that strict behaviour of the teachers rarely fades the inner talents of the students.

Sixth statement was strictness of teachers result in widening the gap between the teachers and the students. As per students' analysis, 19 students ticked 'Always' while, 35 students marked 'Never'. Hence, 18 students said 'Sometimes' in response. That is why, it is clear that majority of the students disagreed with the statement and are of the view that it does not happen but sometimes. Seventh statement was strictness of the teachers result in making the students fed up of their studies. As a response, nine students marked 'Always' in response while, 38 students marked 'Never'. Therefore, it can be derived that a major portion of the students did not agree with the statement. Eighth statement was strictness of the teachers result in decreasing the interest of the students in their studies. As per students' analysis, seven students said 'Always'. Similarly, 46 students said 'Never'. But, 17 students said 'Sometimes'.

So, majority of the students almost denied the statement.

Ninth statement was strictness of the teachers results in making the students stick to their studies \& accomplish their assignments in time. As per students' analysis, 71 students said 'Always' whereas, only one student said 'Never' in response to this statement. Hence, 15 students said 'often' in response. So, a clear portion of the students stood with the statement. The tenth and the final statement in this context was strictness of the teachers result in producing more chances of the dropout of the students from school. In response to it, only seven students ticked 'Always' while, 45 students ticked 'Never'. However, 19 students said 'Sometimes. So, majority of the students did not agree with the statement. It can be concluded that majority of the teachers and students agreed that strictness of the teachers in classroom prove helpful in keeping the students focused on their studies.

Research Question 3: What is the perception of secondary school teachers regarding the impact of inappropriate language used by the teachers in classroom?

Table 5: Percentage \& mean of inappropriate language used by the teacher

\begin{tabular}{lcccccc}
\hline & \multicolumn{7}{c}{ Teachers } \\
\hline Statements & Always & Often & Sometimes & Rarely & Never & Mean \\
\hline $\begin{array}{l}\text { Creates a bad feeling in } \\
\text { the students. }\end{array}$ & 51 & 35 & 10 & 0 & 3 & 4.72 \\
$\begin{array}{l}\text { Inculcates a sense of } \\
\text { responsibility among the } \\
\text { students. }\end{array}$ & 11 & 12 & 11 & 11 & 55 & 2.13 \\
$\begin{array}{l}\text { Strengthens writ of the } \\
\text { teachers on the students. }\end{array}$ & 9 & 18 & 11 & 19 & 43 & 2.31 \\
$\begin{array}{l}\text { Leads the students } \\
\text { towards immorality. }\end{array}$ & 35 & 39 & 17 & 5 & 4 & 3.96 \\
$\begin{array}{l}\text { Destroys the character of } \\
\text { the students. }\end{array}$ & 38 & 35 & 12 & 8 & 7 & 3.89 \\
$\begin{array}{l}\text { Generates extremism in } \\
\text { the students. }\end{array}$ & 28 & 32 & 22 & 12 & 5 & 3.96
\end{tabular}


Journal of Educational Research in Developing Areas (JEREDA)

Vol. 1. Issue 1, Pp. 20-32, Inaugural Edition, 2020

http://www.jeredajournal.com

E-mail: info@jeredajournal.com

The preceding table 5 shows the results of the responses given by the teachers in response to the statements under the heading/factor: Inappropriate language used by the teachers. In this regard, the first statement was inappropriate language used by the teachers create a bad feeling in the students. As per teachers' response, 51 teachers said 'Always', while, only three teachers said 'Never' in response. Hence, 35 teachers marked 'Often' in response. It means, majority of the teachers accepted the statement. The second statement was inappropriate language used by the teachers inculcate a sense of responsibility among the students. In response as per teachers' analysis, 11 teachers said 'Always' and almost half of the population of the teachers i.e. 55 teachers said 'Never' in response. The result is clear that majority of the teachers did not agree with this statement. The third statement was inappropriate language used by the teachers, strengthens wit of the teachers on the students. As per teachers' responses, only 9 teachers say 'Always' and majority i.e. 43 teachers said 'Never'. The fourth statement was inappropriate language used by the teachers lead the students towards immorality. As per teachers' response, 35 teachers ticked 'Always' option. Only four teachers marked 'Never'. While, 39 teachers opted the option of 'Often'. Therefore, it is obvious that majority endorsed with the statement.

Furthermore, the fifth statement was inappropriate language used by the teachers, destroy the character of the students. As per teachers' responses, 38 teachers said 'Always' and only seven teachers said 'Never' in response. Whereas, 35 teachers opted 'Often'. Hence, there remains no ambiguity that majority of teachers agreed with the statement. The sixth and the final statement in this context was inappropriate language used by the teachers in classroom, generates extremism in the students. As per teachers' responses, 28 teachers marked 'Always'. Similarly, in the same way, only five teachers said 'Never'. Hence, 32 teachers marked 'Often'. So, most of the teachers stood with the statements.

Research Question 4: What is the perception of secondary school students regarding the impact of inappropriate language used by the teachers in the classroom?

Table 6: Percentage \& mean of inappropriate language used by the teacher

\begin{tabular}{|c|c|c|c|c|c|c|}
\hline \multirow[b]{2}{*}{ Statements } & \multicolumn{5}{|c|}{ Students } & \multirow[b]{2}{*}{ Mean } \\
\hline & Always & Often & Sometimes & Rarely & Never & \\
\hline $\begin{array}{l}\text { Creates a bad feeling } \\
\text { in the students. }\end{array}$ & 32 & 23 & 26 & 2 & 17 & 3.51 \\
\hline $\begin{array}{l}\text { Inculcates a sense of } \\
\text { responsibility among } \\
\text { the students. }\end{array}$ & 22 & 18 & 7 & 6 & 47 & 2.62 \\
\hline $\begin{array}{l}\text { Strengthens writ of } \\
\text { the teacher on the } \\
\text { students. }\end{array}$ & 22 & 13 & 8 & 17 & 39 & 3.03 \\
\hline $\begin{array}{l}\text { Leads the students } \\
\text { towards immorality. }\end{array}$ & 24 & 38 & 15 & 7 & 16 & 3.47 \\
\hline $\begin{array}{l}\text { Destroys the } \\
\text { character of the } \\
\text { students. }\end{array}$ & 35 & 20 & 14 & 3 & 28 & 3.31 \\
\hline $\begin{array}{l}\text { Generates extremism } \\
\text { in the students. }\end{array}$ & 20 & 24 & 15 & 11 & 30 & 2.93 \\
\hline
\end{tabular}


Journal of Educational Research in Developing Areas (JEREDA)

Vol. 1. Issue 1, Pp. 20-32, Inaugural Edition, 2020

http: / / www.jeredajournal.com

E-mail: info@jeredajournal.com

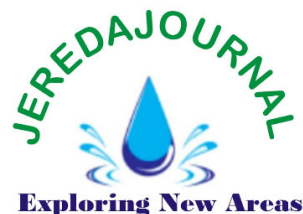

Table above shows the percentage of responses from the students, about the results of inappropriate language used by the teacher in classroom. In this regard, the first statement was inappropriate language used by the teachers create a bad feeling in the students. As per teachers' responses, 32 students said 'Always', while, 17 students said 'Never' in response. Hence, 23 students marked 'Often' in response. Resultantly, it is easy to say that most of the students stayed with the statement. The second statement was inappropriate language used by the teachers inculcate a sense of responsibility among the students. In response, 22 students said 'Always' and almost half of the population of the students i.e. 47 students said 'Never' in response. So, major portion of students did not agree with the statement. The third statement was inappropriate language used by the teachers, strengthens wit of the teachers on the students. As per students' response, 22 students said 'Always' and 39 students said 'Never'. Therefore, an overwhelming majority of students denied the statement. The fourth statement was inappropriate language used by the teachers lead the students towards immorality. While responding to this statement, 24 students ticked 'Always' option. Only 16 students marked 'Never'. Similarly, 38 students opted 'Often'. So, a reasonable amount of students agreed with the statement.

The fifth statement was inappropriate language used by the teachers, destroy the character of the students. In response, 35 students said 'Always' and 28 students said 'Never'. Hence, 20 students ticked the option of 'Often'. In consequence, it is obvious that a fine percentage of the population of the students stood with the statement and agreed with it. The sixth and the final statement in this context was inappropriate language used by the teachers in classroom, generates extremism in the students. In response, 20 students marked 'Always'. Similarly, 30 students said 'Never'. Hence, 24 students marked 'Often'. Thus, a majority student agreeed with the statement. It can be concluded that on average 57 teachers and similarly 49 students agreed on statements of teachers using inappropriate language.

\section{DISCUSSIONS}

Findings bear witness that, majority of the respondents agree with the given factors in a positive way such as the strict behaviour of teachers speed up students' learning, make them reach the class on time, keep students focused on their study, insist on learning, compel them to complete their homework on time. Study of Jane (2016) supports the results of this study and claims that the researchers found that countries with strict disciplinary rules at school performed more academically than expected, and increase students' learning. This research helps to understand the impact of the strict behaviour of teachers on students. Surprisingly, most students believe that the teachers' strict behaviour in the classroom will have a positive effect on the students' learning process. Stronge (2018) believes that teachers have a big impact on students. Professionalism, special attitudes and characteristics of teachers are important in teaching. He further argues that professional teachers always attract students and makes them stronger in their teacher-student relationships.

Nevertheless, on the other hand Aluede, Ojugo and Okoza (2012), say in their study that the use of inappropriate language or emotional abuse by teachers is more destructive than all forms of child abuse. It reduces self-worth and weakens personality of students. If a teacher uses wrong or inappropriate language in class, such behaviour can lead the students to the wrong direction and reduces their confidence. Most of the teachers and students believe that, kind and friendly attitude of teachers and students in the classroom will make a positive difference in the learning environment. They also expressed the same concern that using inappropriate language declines learning capacity of students. Hence, friendly attitudes of teachers in classroom makes the students feel comfortable and relaxed which helps them to study more and increase their learning (Bhargava \& Pathy, 2011). According to Davila (2003), positive relationship between student and teacher significantly put impact on student's achievement, engagement and expectations. It is one of the proved phenomena that positive relationship 
Journal of Educational Research in Developing Areas (JEREDA)

Vol. 1. Issue 1, Pp. 20-32, Inaugural Edition, 2020

http://www.jeredajournal.com

E-mail: info@jeredajournal.com

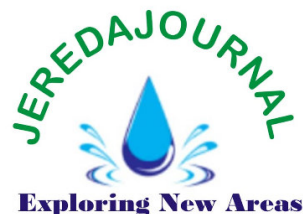

develops strong communication of a teacher with his/her students that paves the way of success for the students.

\section{CONCLUSION}

Regardless of tremendous critique on strictness behaviorus of teachers in classroom especially in this modern society, the study has a positive impact in developing societies like underprivileged areas of Pakistan, where students are not that refined from their homes because of poor financial conditions of their families and sometimes due to ingrained culture. In some aspects, it offers positive results, while in other aspects, it shows negative consequences too. But the current study proves strictness of a teachers in classroom positive, in favour of creating learning environment and keeping students stick to their studies. The study denotes almost similar responses from both teachers and students. Whereas, both teachers and students think that inappropriate language does not suit a teacher in any way rather it throws negativity on the minds of students, as revealed in the findings of this study. Hence, generally teachers need to be extracareful in their conduct in classroom, because their actions are copied.

\section{RECOMMENDATIONS}

This study has been conducted in a specified area of Pakistan with a limited scope, which is quite insufficient. Every place has its own behavioUral norms due to different socio-economic and geographical conditions. Baluchistan is socioeconomically weaker than the rest of Pakistan. Geographically, it is an arid land with low quality of life. Culturally people are more conservative and follow tribal system. Quetta being the capital of Baluchistan presents the holistic picture of the entire province. Therefore in order to gain a deeper insight of the issue, this study requires to be carried upon at a larger scale in an alike socio-economic culture and in different other societies, communities, and cultures to have a bigger insight of the problem. That will eventually help in understanding this debatable issue with a more vivid view.

Since secondary schools' teachers and students are the focus of this study, the further studies need to be expended at

secondary schools in different parts of the world, as well as it requires to be spread over multiple levels of schooling and classrooms.

Conflicts of Interest: The author declares no conflict of interest.

Disclaimer Statement: This article has been written from the $M$. Phil thesis work conducted in 2019 at Virtual University of Pakistan under the supervision of Dr. Asif Jamil Khan professor emeritus, Qurtuba College Dera Ismail Khan, KPK, Pakistan.

Notes on Author: The author of this study is an $M$. Phil scholar in Education, graduated from Virtual University of Pakistan in the year 2020. Currently working as a secondary school teachers at Government Boys High School Satellite Town Quetta, Pakistan. His study interest focuses classroom environment, teacher behaviour, and students' learning. He is also Teaching Excellence \& Achievement (TEA) alumnus, attended at Virginia Tech University, USA in 2019.

\section{REFERENCES}

Aluede, O., Ojugo, A. I., \& Okoza, J. (2012). Emotional abuse of secondary school students by teachers in Edo State, Nigeria. Research in Education, 88(1), 29-39.

Bhargava, A., \& Pathy, M. (2011). Perception of student teachers about teaching competencies. American International Journal of Contemporary Research, 1(1), 77-81.

Cook, A., Spinazzola, J., Ford, J., Lanktree, C., Blaustein, M., Cloitre, M. \& Mallah, K. (2017). Complex trauma in children and adolescents. Psychiatric annals, 35(5), 390-398.

Davila, E.R. (2003). What about the teachers and the classes? Puerto Rican students in Chicago share their experience. Proceedings of Annual Meeting of the American Educational Research Association. Chicago, IL. https://eric.ed.gov/?id=ED478620.

Flick, U. (2015). Introducing research methodology: A beginner's guide to doing a research project. Sage.

Jane, H. (2016, November). Does strict discipline pay off in the classroom? 
Journal of Educational Research in Developing Areas (JEREDA)

Vol. 1. Issue 1, Pp. 20-32, Inaugural Edition, 2020

http://www.jeredajournal.com

E-mail: info@jeredajournal.com

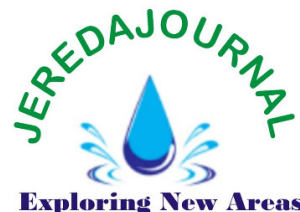

https://www.theeducatoronline.com/k

$12 /$ news/does-strict-discipline-pay-

off-in-the-classroom/226498.

Mercer, S., \& De-Rosier, M. (2010). A prospective investigation of teacher preference and children's perceptions of the student teacher relationship. Psychology in the Schools, 47(2), 184-192.

Mundy, K. (1999). Educational multilateralism in a changing world order: UNESCO and the limits of the possible. International Journal of Educational Development, 19(1), 2752.

Prochaska, J. O., Di Clemente, C. C., \& Norcross, J. C. (1992). In search of how people change: Applications to addictive behaviors. American psychologist, 47(9), 1102.

Shah, S. S. A. (2009). Impact of Teachers Behaviour on The Academic Achievement Of University Students. Journal of College Teaching \& Learning, 6(1) 69-73.

Somerville, L. H. (2013). The teenage brain: Sensitivity to social evaluation. Current directions in psychological science, 22(2), 121127.

Soroya, M. S., Hashmi, M. A., \& Soroya, S. H. (2014). Student-teacher relationship and its impact on academic integrity: A case of university of the Punjab. Pakistan Library \& Information Science Journal, 45(2).41-48.

Starr, C., \& Taggart, R. (1992). Integration and control: Endocrine systems. biology-the unity and diversity of life. Wadsworth Publishing Company.

Stronge, J. H. (2018). Qualities of effective teachers. ASCD. 